\title{
CAN TOUR GUIDES PROTECT THE MARINE AND COASTAL ENVIRONMENT FROM MASS TOURISM IMPACTS: SITUATION OF ANDAMAN OCEAN, THAILAND, PRE-COVID-19
}

\author{
Pruessayos JITSUMPUN \\ Prince of Songkla University, Faculty of Environmental Management, Kor Hong, Hat Yai, Thailand, e-mail: pruessayos@gmail.com \\ Umaporn MUNEENAM" \\ Prince of Songkla University, Faculty of Environmental Management, Kor Hong, Hat Yai, Thailand, e-mail: umaporn.m@psu.ac.th
}

\begin{abstract}
Citation: Jitsumpun, P., \& Muneenam, U. (2021). CAN TOUR GUIDES PROTECT THE MARINE AND COASTAL ENVIRONMENT FROM MASS TOURISM IMPACTS: SITUATION OF ANDAMAN OCEAN, THAILAND, PRE-COVID19. GeoJournal of Tourism and Geosites, 39(4spl), 1325-1330. https://doi.org/10.30892/gtg.394spl01-774
\end{abstract}

\begin{abstract}
This article studies the role of Thai guides in protecting marine and coastal environment against impacts from international tourism, in the Andaman Ocean, Thailand. This is a qualitative study with in-depth interviews of 26 licensed guides that were selected by using purposive and snowball sampling. Quantitative data were analyzed with descriptive statistics, and qualitative data from in-depth interviews and field notes were analyzed with qualitative data analysis. The results show that behaviors affecting marine and coastal environment mostly involve chasing and catching beautiful fish and/or marine animals (76.9\%), feeding fish $(73.1 \%)$, and collecting beautiful stones, rare shells, and/or coral reefs $(73.1 \%)$. Guides act in the roles of educator, psychologist, entertainer, ambassador, and servant, and protect against impacts to the extent that they can. While some impacts can be avoided, others remain out of scope and control of the guides.
\end{abstract}

Key words: Tour Guides Roles, Marine and Coastal Environmental Protection, Mass Tourism, Andaman Ocean, Thailand

$* * * * *$

\section{INTRODUCTION}

Thailand is one of the dream destinations of tourists from many countries around the world. For example, World Tourism Organization (UNWTO) (2021) reported that, in 2019, Thailand was ranked eighth of the World's top 10 destinations and received 40 million international tourist arrivals, and was fourth in revenue earned from tourism activities. This was about 20 percent of Thailand's GDP (Damronkijakarn, 2020). Besides, this agrees with what the Ministry of Tourism and Sports (2017) in Thailand has stated about the growth factors supporting tourism industry in Thailand, including the growth of mid-level society and of their income, of low-cost airlines, of tourism expenditures with elderly visitors, convenient technologies for tourism, and the need of in-depth tourism experiences.

Thailand has a wide variety of tourism resources, such as rivers, oceans, mountains, and cultural contexts. One of the most distinctive tourism activities in Thailand is marine and coastal tourism in southern peninsular Thailand with Gulf of Thailand and the Andaman Ocean. Hotspots of marine and coastal tourism at the Andaman Ocean shores for tourists include Phuket, Krabi, and Phangnga provinces that are by the seashore and have access to convenient transportation. Phuket is the dominant hub of tourism among these provinces, with international airport and transportation, and welldeveloped tourism agencies, restaurants, accommodations, and souvenir shops. Therefore, the numbers of international tourists have grown until the current Covid-19 pandemic, including mass tourism (Office of Phuket Statistics Organization, 2019).

Although mass tourism creates employment and generates high revenue to the country (Astina et al., 2021), mass tourists have been accused of highly negative impacts to the environment. Especially so in the context of marine and coastal tourism that is popular among mass international tourists. For example, the marine and coastal resources are overcrowded, with damage potentially to coral reefs or natural fish and marine animals, and/or the visitors leave unwanted waste in the ocean (Thongtham et al., 2003). Tour guides are then important persons working with the tour operators, interacting and always giving tourism services to these mass tourists, due to their roles in providing knowledge and guidance to the tourists (Maakjaeng, 1991), and similar to environmental interpreters according to the definition of Knudson et al. (1999) that could finally guide tourists to environmentally sound practices (Skibins, 2016; Tilden, 1977).

Recently, the Department of Tourism (2015) in Thailand reported that there are totally 2,696 Thai tour guides - an occupation allowed only for Thai nationals - that have been registered with the Bureau of Tourism Business and Guide Registration Southern Region 2 (Phuket). Thus, marine and coastal tour guides for international tourists should hold yellow (beach tourism permission), orange (marine tourism permission), pink (international tourists at specific areas permission: only in Phuket, Krabi, and Phangnga Provinces), blue (Southern Provinces, Thailand permission after 18 April 2019) and/or silver (international tourist permission) certificate licenses that are renewed every five years (Matichononline, 25.3.2019).

Consequently, this study aimed to assess whether Thai tour guides are able to protect marine and coastal environment against impacts from mass and coastal tourism, specific to one foreign nationality, based on roles of the Thai tour guides in

* Corresponding author 
marine and coastal mass tourism affecting the marine and coastal tourism resources; as well as to present the results on their roles affecting marine and coastal tourism behavior of one specific nationality of tourists.

\section{LITERATURE REVIEW}

\section{Thai Tour Guide}

The tour guides in Thailand were defined recently in the Tourism Business and Guide Act B.E. 2016 (Ratchakitchanubeksa, 2016), in alignment with the earlier proposal by Prakash and Chowdhary (2010). The designation means a person of Thai nationality, over 18 years old, who as a service guides tourists to various places, providing recommendations and information to the tourists. Tour guide has to be qualified by education and/or training, then register, and be granted a license by the government (Ratchakitchanubeksa, 2016). There were ten types of tour guide licenses divided by tourism activities, and after 18 April 2019 these have been reduced to only six types of tour guide licenses divided by region in Thailand; however, these two systems still overlap especially for the ones who are not due for renewal from the old system. In the context of this study, marine and coastal tour guides for international tourists should hold yellow (beach tourism permission), orange (marine tourism permission), pink (international tourists at specific areas permission: only in Phuket, Krabi, and Phangnga Provinces), blue (Southern Provinces, Thailand permission after 18 April 2019) and/or silver (international tourist permission) certificate licenses (Matichononline, 25.3.2019).

Makjaeng (1991) described the two major roles of a tour guide as follows: one is the role as a representative of the country; another role is as the guide. This latter role explains in detail the guiding roles that the tour guide has during transfer-in, tour, and transfer-out. In these stages the role of a tour guide is more than just providing information to the tourists. In reality, sometimes a distinction is made between a tour guide who only informs tourists, and a guide who transfers tourists in and out and is called a transfer guide (Maakjaeng, 1991). In addition, Wanthanom (2014); Banerjee and Chua (2020); and Mackenzie and Raymond (2020) explained the roles of a tour guide falling into six types, and used these for investigating their roles in protecting the marine and coastal resources from mass tourism impacts in the study. These roles are those of an educator, a psychologist, an entertainer, an ambassador, a manager, and a servant.

\section{Tour Operator}

Tour operator or tourism business in the context of Thailand means a business that provides one of the following services to tourists: lodging, food, tour guides, or other services that are prescribed in the Ministerial Regulation. The meaning is similar to the meaning of 'mass tourism', inclusive of tours, package tours, or using services of a tour operator (one type of tourism), and excluding 'independent tourism'. Mass tourism means that the tourists have a tour operator decide itinerary, accommodation, and travel plan for them (Maakjaeng, 1991). One that wants to have tourism business has to register with and be licensed by the government. A licensed tour operator can be an individual or a juristic person; however, a tour operator doing tourism business without the required license may be punished by jailing for not more than two years, and/or may be fined not more than five hundred thousand bath (Ratchakitchanubeksa, 2016).

\section{Relationship of Licensed Tour Operator and Licensed Tour Guide}

A licensed tour operator doing business in mass tourism usually provides licensed tour guides. The tour guide may freelance for the tour operator company and come to work when the tour operator calls for assistance, or be part of the regular staff of the tour operator company. They habitually pick up (transfer-in) the tourists from the first destination, such as and airport or a hotel; then guide a tour; and send (transfer-out) the tourists back home safely. During the tour guiding, it may be that the tour guide takes the tourists to visit places where they also provide a personal interpretation or a non-personal interpretation. A tour guide who takes tourists with the tour operator company may also give rough information of the place, and then let the tourists have free time to learn by themselves, or to learn from a local speaker in that place; such as Talang National Museum, Phuket, which provides both personal and non-personal interpretations (Muneenam et al., 2017). In addition, a licensed tour guide has to be a proficient communicator, giving correct information to the tourists, and entertaining them so that they enjoy their tour. The mother tongue is insufficient, instead also foreign languages are used, especially by the inbound tour guide.

\section{Positive and Negative Impacts of Mass Tourism}

Generally, there are both positive and negative impacts from tourism. Three main aspects of impacts are observed: environmental, economic, and socio-cultural impacts (Weaver, 2001; Dimitrovski et al., 2021). For example, Weaver (2001) mentioned some positive impacts from mass tourism as: information from tour guide is able to protect tourism resources during the visit; and increased jobs, incomes, and well-being in local communities. On the other side, negative impacts from mass tourism include wastes, disturbing marine species by tourist observation activities (Chen et al., 2012; Moschino et al., 2017), high expenses, revenue leakage from non-local participation, and socio-cultural intrusion.

This research focuses only on the positive impacts of tour guides while doing their jobs, as well as the negative impacts of tourist activities; and whether tour guide roles can protect marine and coastal resources from mass tourism impacts, specific to one foreign nationality engaging in mass tourism at the Andaman Ocean, Thailand.

\section{Mass Tourism at Marine and Coastal Environment}

As mentioned earlier about the definition of mass tourism by Maakjaeng (1991), this study focuses on mass tourism especially at marine and coastal environment, due to it being a very popular among the foreign mass tourists that could negatively impact the marine and coastal environment. Marine and coastal tourism overlaps with nature-based tourism (Biggs et al., 2015), sea-sand-sun tourism (3s) (Weaver, 2001), and water-based tourism (Fowler, 2012). However, the 
most suitable definition for the context of this study is 'marine and coastal tourism' due to coverage of the main activities in the itinerary (Table 1). Dimitrovski et al. (2021) define marine and coastal tourism as recreational activities during travel away from one's place of residence that focus on marine environment and/or a coastal zone. Marine and coastal recreational activities could be boating, swimming, snorkeling, diving, sunbathing, beachcombing, etc.

An interview schedule was developed based on prior literature and assessed for content validity indexes (CVIs) by three experts, and it was revised before use (Thaweerat, 1993). Data collection was from Thai licensed tour guides serving one specific foreign nationality, and working with licensed tour operators registered with the Bureau of Tourism Business and Guide Registration Southern Region 2 (Phuket): there were totally 26 tour operators. They were selected by using purposive and snowball sampling to have one representative per each tour operator. Finally, the 26 representative Thai tour guides were subjected to in-depth interviews (Table 2) with interview schedule divided into 4 sections (Section 1: Basic information of the tour guide; Section 2: Tourist behaviors affecting marine and coastal environment; Section 3: Roles of tour guide; and Section 4: Results from the roles of Thai tour guides on the marine and coastal tourism behavior). In addition to taking notes, voice recordings were made with permission. Quantitative data of the tour guides' basic information were analyzed with descriptive statistics in SPSS (Statistical Package for the Social Sciences) on a personal computer. In-depth interviews were transcribed and coded, and analyzed in-depth together with field notes in qualitative data analysis (Chantavanij, 2008).

Table 1. A generic itinerary of marine and coastal tourism from four to six days marketed by Phuket tour operators, Thailand (Source: Jiayun Travel Group Company Limited, 2018)

\begin{tabular}{|c|c|c|c|}
\hline Days & 4 Days Program & 5 Days Program & 6 Days Program \\
\hline $\begin{array}{c}\text { Day } \\
1\end{array}$ & $\begin{array}{l}\text { Arrival to Phuket } \\
\text { via Bangkok or } \\
\text { directly to Phuket }\end{array}$ & $\begin{array}{l}\text { Arrival to Phuket via } \\
\text { Bangkok or directly } \\
\text { to Phuket }\end{array}$ & $\begin{array}{l}\text { Arrival to Phuket via } \\
\text { Bangkok or directly } \\
\text { to Phuket }\end{array}$ \\
\hline $\begin{array}{c}\text { Day } \\
2\end{array}$ & $\begin{array}{l}\text { Phangnga Province } \\
\text { - PanYhee Island } \\
\text { - Tapu Island (007 } \\
\text { James Bond Island) } \\
\text { - Thamlod (Cave) } \\
\text { - Safari Tour } \\
\text { - Night Show } \\
\end{array}$ & $\begin{array}{l}\text { Phangnga Province } \\
\text { - PanYhee Island } \\
\text { - Tapu Island (007 } \\
\text { James Bond Island) } \\
\text { - Thamlod (Cave) } \\
\text { - Safari Tour } \\
\text { - Night Show }\end{array}$ & $\begin{array}{l}\text { Phangnga Province } \\
\text { - PanYhee Island } \\
\text { - Tapu Island (007 } \\
\text { James Bond Island) } \\
\text { - Thamlod (Cave) } \\
\text { - Safari Tour } \\
\text { - Night Show }\end{array}$ \\
\hline $\begin{array}{c}\text { Day } \\
3\end{array}$ & $\begin{array}{l}\text { Krabi Province } \\
\text { - Phi Phi Island } \\
\text { - Maya Bay } \\
\text { - Pile Island } \\
\text { - Pai Island } \\
\text { - Khainai Island } \\
\end{array}$ & $\begin{array}{l}\text { Krabi Province } \\
\text { - Phi Phi Island } \\
\text { - Maya Bay } \\
\text { - Pile Island } \\
\text { - Pai Island } \\
\text { - Khainai Island } \\
\end{array}$ & $\begin{array}{l}\text { Phangnga Province } \\
\text { - Similan Island }\end{array}$ \\
\hline $\begin{array}{c}\text { Day } \\
4\end{array}$ & $\begin{array}{l}\text { Phuket Province } \\
\text { - Shopping Day } \\
\text { - Hey Island } \\
\text { - Promthem Bay } \\
\text { Departure from } \\
\text { Phuket }\end{array}$ & Free Day & $\begin{array}{l}\text { Krabi Province } \\
\text { - Phi Phi Island } \\
\text { - Maya Bay } \\
\text { - Pile Island } \\
\text { - Pai Island } \\
\text { - Khainai Island } \\
\end{array}$ \\
\hline $\begin{array}{l}\text { Day } \\
5\end{array}$ & - & $\begin{array}{l}\text { Phuket Province } \\
\text { - Shopping Day } \\
\text { - Hey Island } \\
\text { - Promthem Bay } \\
\text { Departure from Phuket }\end{array}$ & Free Day \\
\hline $\begin{array}{l}\text { Day } \\
6\end{array}$ & - & - & $\begin{array}{l}\text { Phuket Province } \\
\text { - Shopping Day } \\
\text { - Hey Island } \\
\text { - Promthem Bay } \\
\text { Departure from Phuket }\end{array}$ \\
\hline
\end{tabular}

\section{MATERIALS AND METHODS}

This was a qualitative study of the marine and coastal tourism in three provinces: Phuket, Phangnga, and Krabi provinces, by the Andaman Ocean in southern peninsular Thailand. An example itinerary is shown in Table 1.

Table 2. Representative interviewees

from 26 tour operators ordered by date of interview

\begin{tabular}{|l|c|}
\hline \multicolumn{1}{|c|}{ Case of Interviewees } & Date of Interview \\
\hline Tour Guide Case 1 & 23 February 2020 \\
\hline Tour Guide Case 2, 3,4 & 24 February 2020 \\
\hline Tour Guide Case 5, 6, 7 & 26 February 2020 \\
\hline Tour Guide Case $\mathbf{8 , 9 , 1 0}$ & 27 February 2020 \\
\hline Tour Guide Case 11, 12, 13, 14, 15 & 28 February 2020 \\
\hline Tour Guide Case 16 & 29 February 2020 \\
\hline Tour Guide Case 17, 18, 19 & 1 March 2020 \\
\hline Tour Guide Case 20, 21, 22, 23, 24, 25 & 2 March 2020 \\
\hline Tour Guide Case 26 & 3 March 2020 \\
\hline
\end{tabular}

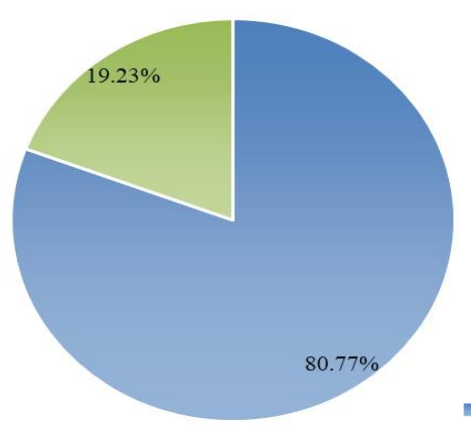

Figure 1. Basic information of the interviewees regarding gender $(n=26)$

\section{RESULTS AND DISCUSSION}

\section{Section 1. Basic Information of Interviewees}

Figure one to four presents basic information of the interviewees and shows that there were more females $(80.77 \%)$ than males (19.23\%). The dominant age (Figure 2) range was from 30 to 33 years old (50.00\%), most of the subjects had graduated (Figure 3) with bachelor's level degree (88.46\%), and half of them had experience (Figure 4) of six to ten years $(50.00 \%)$. Table 3 presents additional basic information of the interviewees regarding their licenses as well as types of work, showing that most of those who hold silver certificate license $(92.31 \%)$ graduated with a bachelor's degree and a few have high vocational certificate levels. Those who hold yellow (3.85\%) and orange certificate licenses (3.85\%) have mostly graduated from secondary or vocational education level. This is concordant with the Tourism Business and Guide Act B.E. 2008 in that tour guides who have graduated at bachelor's and/or high vocational certificate levels in tourism or related fields will automatically receive silver certificate licenses after graduation. Those who hold yellow and orange certificate licenses and graduated from secondary / vocational certificate level have to pass training from vocational college or a training program from a certified educational institute. In addition, all licensed tour guides have to be over 18 years old without unqualifying conditions, such as drug and/or alcohol addiction, or having their license revoked within the most recent five years (Office of the Council of State, 2008). Besides, most of them operate as freelance (92.31\%) rather than as 
full-time tour guides for a specific tour operator (7.69\%). Table 4 presents popular destinations of marine and coastal tourism in the three provinces for tourists from one specific foreign country, showing that the Thai tour guides had to lead their target tourists to visit the following top destinations: Tapu Island or 007 James Bond Island, Phangnga Province (96.15\%), Phi Phi Island, Krabi Province (96.15\%), or Hey Island, Phuket Province (92.31\%). Table 5 presents the distribution of durations of marine and coastal tourism packages from one to more than six days, showing that most licensed tour guides serve on 5 days long marine and coastal tourism packages $(69.23 \%)$, while one-day tours employ the least marine and coastal tour guides (7.69\%). Table 6 presents size of marine and coastal tourist groups. Mostly the guides worked for at most 30 tourists $(88.46 \%)$ in the group; while one third of them had more than 30 tourists $(34.62 \%)$.

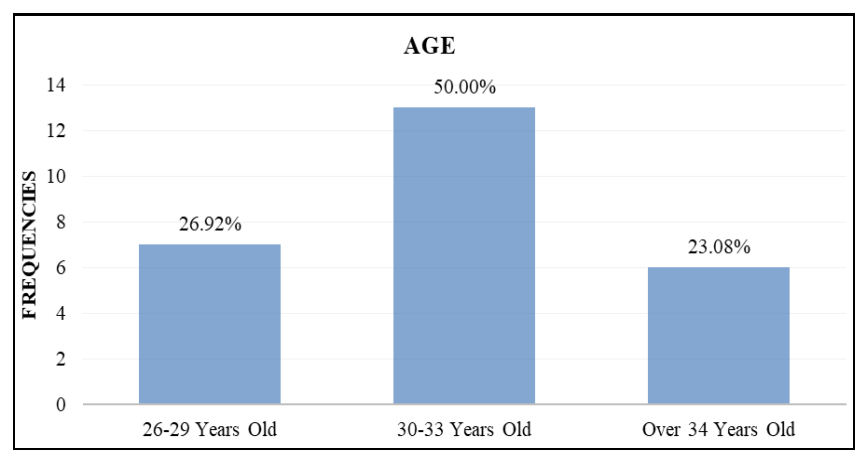

Figure 2. Basic information

of the interviewees regarding age $(n=26)$

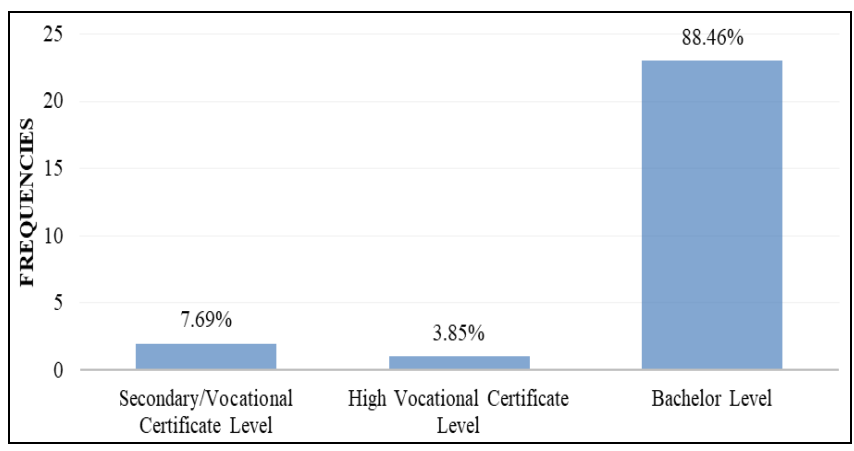

Figure 3. Basic information of the interviewees regarding education $(n=26)$

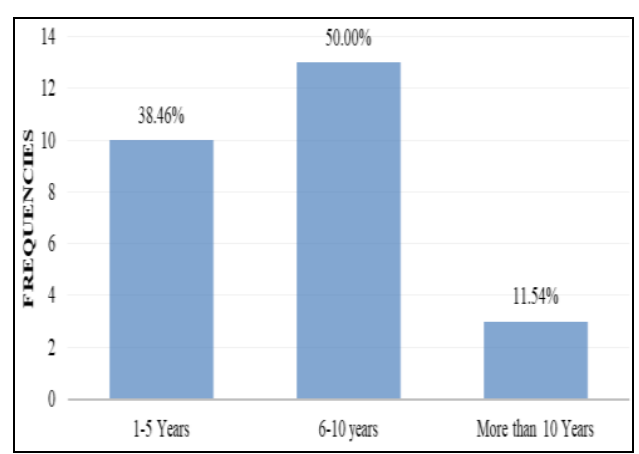

Figure 4. Basic information of the interviewees regarding work experience $(n=26)$

Table 3. Basic information of interviewees by license, type of work, cross-tabulated by education level $(n=26)$

\begin{tabular}{|l|c|c|c|c|}
\hline \multirow{2}{*}{$\begin{array}{c}\text { Basic Information } \\
\text { of Interviewees }\end{array}$} & \multicolumn{4}{|c|}{ Frequencies and Percentages (\%) } \\
\cline { 2 - 5 } Type of License & $\begin{array}{c}\text { Secondary/Vocational } \\
\text { Certificate Level }\end{array}$ & $\begin{array}{c}\text { High Vocational } \\
\text { Certificate Level }\end{array}$ & $\begin{array}{c}\text { Bachelor } \\
\text { Level }\end{array}$ & SUM \\
\hline Silver & - & $1(3.85 \%)$ & $23(88.46 \%)$ & $24(92.31 \%)$ \\
\hline Yellow & $1(3.85 \%)$ & - & - & $1(3.85 \%)$ \\
\hline Orange & $1(3.85 \%)$ & - & - & $1(3.85 \%)$ \\
\hline SUM & $2(7.69 \%)$ & $1(3.85 \%)$ & $23(88.46 \%)$ & $26(100.00 \%)$ \\
\hline \multicolumn{5}{|c|}{ Type of Work } \\
\hline Freelance & $2(7.69 \%)$ & $1(3.85 \%)$ & $21(80.77 \%)$ & $24(92.31 \%)$ \\
\hline Full Time Officer & - & - & $2(7.69 \%)$ & $2(7.69 \%)$ \\
\hline SUM & $2(7.69 \%)$ & $1(3.85 \%)$ & $24(92.31 \%)$ & $26(100.00 \%)$ \\
\hline
\end{tabular}

Table 4. Marine and coastal tourism hotspot destinations by province supported by interviewee responses of at least two interviewees $(\mathrm{n}=26)$

\begin{tabular}{|l|c|c|}
\hline \multicolumn{1}{|c|}{$\begin{array}{c}\text { Marine and Coastal Tourism } \\
\text { Destination }\end{array}$} & Frequency & $\begin{array}{c}\text { Percentage } \\
(\%)\end{array}$ \\
\hline \multicolumn{3}{|c|}{ Phangnga Province } \\
\hline Tapu Island (007 James Bond Island) & 25 & 96.15 \\
\hline PanYhee Island & 22 & 84.62 \\
\hline Similan Island & 15 & 57.69 \\
\hline Thamlod (Cave) & 11 & 42.31 \\
\hline \multicolumn{3}{|c|}{ Khabi Phi Island Province } \\
\hline Pile Island & 25 & 96.15 \\
\hline Maya Bay & 18 & 69.23 \\
\hline Pai Island & 15 & 57.69 \\
\hline Hey Island & 14 & 53.85 \\
\hline Promthep Bay & 24 & 92.31 \\
\hline Khainai Island & 21 & 80.77 \\
\hline
\end{tabular}

Table 5. Duration of marine and coastal tourism package as supported by interviewee responses of at least two interviewees $(n=26)$

\begin{tabular}{|l|r|r|}
\hline $\begin{array}{c}\text { Duration of Marine and } \\
\text { Coastal Tourism Package }\end{array}$ & Frequency & Percentage (\%) \\
\hline One Day Tour & 2 & 7.69 \\
\hline 4 days & 7 & 26.92 \\
\hline 5 Days & 18 & 69.23 \\
\hline 6 Days & 13 & 50.00 \\
\hline More than 6 Days & 8 & 30.77 \\
\hline
\end{tabular}

Table 6. Size of Marine and coastal Tourist Group supported by interviewee responses of at least two interviewees $(n=26)$

\begin{tabular}{|l|r|r|}
\hline $\begin{array}{c}\text { Size of Marine and Coastal Tourist } \\
\text { Group }\end{array}$ & $\begin{array}{c}\text { Freque } \\
\text { ncy }\end{array}$ & $\begin{array}{r}\text { Percent } \\
\text { age (\%) }\end{array}$ \\
\hline Less than or equal 30 tourists & 23 & 88.46 \\
\hline More than 30 tourists & 9 & 34.62 \\
\hline
\end{tabular}

Table 7. Tourist behaviors affecting marine and coastal environment negatively, supported by interviewee responses of at least two interviewees $(n=26)$

\begin{tabular}{|l|r|r|}
\hline $\begin{array}{l}\text { Tourist Behaviors Affecting Marine } \\
\text { and Coastal Environment Negatively }\end{array}$ & Frequency & $\begin{array}{r}\text { Percentage } \\
\text { (\%) }\end{array}$ \\
\hline $\begin{array}{l}\text { Chasing and catching beautiful fish } \\
\text { and/or marine animals }\end{array}$ & 20 & 76.9 \\
\hline Feeding the fish & 19 & 73.1 \\
\hline $\begin{array}{l}\text { Collecting beautiful stones, rare } \\
\text { shells, and/or coral reefs }\end{array}$ & 19 & 73.1 \\
\hline $\begin{array}{l}\text { Stumbling on, breaking, bumping in, } \\
\text { and/or moving coral during marine } \\
\text { activities }\end{array}$ & 14 & 53.8 \\
\hline Littering the ocean & 14 & 53.8 \\
\hline Using coral unfriendly sunscreen & 12 & 46.2 \\
\hline $\begin{array}{l}\text { Eating forbidden types of fish such as } \\
\text { parrotfish }\end{array}$ & 5 & 19.2 \\
\hline $\begin{array}{l}\text { Buying forbidden marine animals or } \\
\text { products }\end{array}$ & 1 & 3.8 \\
\hline $\begin{array}{l}\text { Perturbing the sediment with } \\
\text { swimming fins }\end{array}$ & 1 & 3.8 \\
\hline
\end{tabular}


Section 2. Behaviors of Tourists of One Specific Nationality Affecting the Marine and Coastal Environment

Table 7 presents views of the Thai licensed tour guides about tourist behavior for one specific nationality as it affects the marine and coastal environment in Phuket, Phangnga, and Krabi provinces, Thailand. The highest impact tourist behaviors were chasing and catching beautiful fish and/or marine animals (76.9\%); secondly, feeding the fish and collecting beautiful stones, rare shells, and/or coral reefs at a similar level (73.1\%); while very few tourists were buying forbidden marine animals or products or perturbing the sediment with swimming fins (3.8\%). These behaviors are similar to those reported by Matichononline (29.5.2016) from tourist behaviors on Khainai Island, in Phuket province, not far from the coastline, namely that catching fish and feeding the fish could impede growth and development of the fish and harm ecology (Sa-nguansil, 2015), while collecting coral and littering also harm the ocean.

\section{Section 3. Role of Thai Tour Guides in Protecting Marine and Coastal Environment from Tourists}

This section presents roles of Thai tour guides, as they acted in the following roles to protect the marine and coastal environment from behavior of tourists of a specific nationality, except the role as a manager did not appear to have any relationship with protecting marine and coastal environment from tourists.

1) Role of Educational Guidance Thai tour guides had to explain information about Thailand, laws and regulations regarding marine and coastal tourism activities, as do and don't lists, in order to make tourists adapt to the marine and coastal tourism resources, and this information could help protect the marine and coastal environment from tourist activities.

2) Role of Psychologist Thai tour guides had to observe their group of tourists who were a bit varied in preferences by age, gender, knowledge and career. For example, a group of elderly people might be distracted while the tour guide had warned and cautioned about the marine and coastal environment, which could lead to breaking rules of marine and coastal tourism and/or a serious accident. This is similar to what Weng et al. (2020) mentioned, namely that the limitations of elderly tourists include degraded ability to follow or accept explanations.

3) Role of Entertainer Tour guides had to entertain tourists as much as possible to make the tourists pleased with the trip in Thailand. For example, they had to master the art of telling amusing stories, but these could be about permissions to marine and coastal tourists, from some previous group that could have been fined heavily for violations. These exciting and amusing stories were also education, making the guests aware of rules for the marine and coastal environment.

4) Role of Ambassador Tour guides had to cultivate good relationships of Thais with the tourist group, sharing information that helps interactions between the two cultures, such as manners in trading and other interactions, introducing places to visit, where to buy inexpensive souvenirs, and where to enjoy delicious food. Such information contributes to a good image of Thailand that the tourists can share back at home, encouraging visits to Thailand in the future. The trust gained also improves obedience to the tour guide during marine and coastal tourism activities.

5) Role of Servant Tour guide had to be service minded, advising and facilitating tourism under the laws and regulations of marine and coastal tourism. For example, taking care specially of kids and the elderly with limited mobility (Weng et al., 2020), as well as making the others wear life jackets before snorkeling as this could help avoid breaking coral unintentionally.

\section{Section 4. Results Obtained on Roles of Tour Guide Affecting Marine and Coastal Tourism Behavior}

This section presents the results obtained on roles of Thai tour guides, as they affect marine and coastal tourism behavior in a specific nationality of mass tourists. It was found that they could control and protect marine and coastal environment, by providing the tourists knowledge about laws and regulations of marine and coastal tourism in Thailand. This could reduce the impacts on marine and coastal tourism resources, as the tourists did not catch fish or other marine animals. In addition, the tourists enjoyed their time and were satisfied with the marine and coastal tourism services in Thailand.

However, not all Thai tour guide roles help avoid negative marine and coastal tourism impacts on the marine and coastal environment. For example, some of the tourists were distracted from listening when the tour guide explained what to do and not do in marine and coastal tourism activities, even though there were also signs and written instructions in the native language of the tourists to reduce miscommunication, available at tourist destination, supplementing the information shared by the tour guide. This hampered their knowledge of marine ecology concerns as well as laws and regulations in Thailand. Some tourists still fed the fish secretly, or smuggled collected beautiful corals and rare shells. This is also concordant with the barriers to communication according to the Organization for Economic Co-operation and Development (1999:16) which mentioned that "said is not heard, heard is not understood, understood is not accepted, and accepted is not yet done". In addition, regarding loss of the information shared by the tour guide, not all of the tourists were interested in listening at the same time. Some tourists might prefer to be taking photos, and wanted the tour guide to not spend much time talking (Muneenam et al., 2017). Moreover, some marine and coastal tourism resource impacts were from overcrowding by mass tourists from different countries, especially before the COVID-19 pandemic; and catching beautiful fish for tourist photos was sometimes done by a boat driver, not by the tour guide or the tourists themselves. These events were out of scope for the tour guide roles. Also, extra marine activities of tourists in their free time (Table 1) were not under control by the tour guides, such as sea walking, scuba diving, jet skiing, and speed boating.

Although there were successful and unsuccessful Thai tour guide roles affecting marine and coastal tourism behavior by one specific nationality, the respondent Thai tour guides stated that this group of tourists is as nice and kind as any other. Communication in a common language that both parties understand, as well as communication from the heart by the Thai tour guide are important to the tour guide roles in protecting marine and coastal environment from tourist behaviors.

\section{CONCLUSION}

This study presented roles of Thai tour guides in protecting the marine and coastal environment from mass tourists representing one specific (but unnamed) nationality in three provinces at Andaman ocean shores, in southern peninsular 
Thailand, and found that their five roles were helpful in controlling and protecting against impacts on the marine and coastal environment: the roles of educator, psychologist, entertainer, ambassador, and servant. However, while these roles could control some impacts on the marine and coastal environment, other impacts emerged from barriers to communication, limited carrying capacity of marine and coastal ecology despite cumulative tourism, and uncontrolled impacts out of control by the Thai tour guides. Solutions to address these concerns warrant future research studies.

\section{Acknowledgement}

The authors wish to thank the Graduate School, Prince of Songkla University, for research funding in the fiscal year 2019, all participating interviewees, and the proofreading service performed by Assoc. Prof. Seppo Karrila on behalf of the Publication Clinic, Research and Development Office, Prince of Songkla University.

\section{REFERENCES}

Astina, I.K., Sumarmi, \& Kurniawati, E. (2021). Tourism coastal areas: Its implication to improve economic and cultureation (Case study in GOA China Beach, Malang). GeoJournal of Tourism and Geosites, 37(3), 740-746. https://doi.org/10.30892/gtg.37302-704

Banerjee, S., \& Chua, A.Y.K. (2020). How alluring is the online profile of tour guides? Annals of Tourism Research, 81(2020). https://doi.org/10.1016/j.annals.2020.102887

Biggs, D., Hicks, C.C., Cinner, J.E., \& Hall, C.M. (2015). Marine tourism in the face of global change: The resilience of enterprises to crises in Thailand and Australia. Ocean \& Coastal Management, 105(2015), 65-74. https://doi.org/10.1016/j.ocecoaman.2014.12.019

Chantavanij, S. (2008). Qualitative data analysis. CU Press, Bangkok, Thailand, (in Thailand).

Chen, T.C., Ku, K.C., \& Ying, T.C. (2012). A process-based collaborative model of marine tourism service system - The case of Green Island area, Taiwan. Ocean \& Coastal Management, 64(2012), 37-46. https://doi.org/10.1016/j.ocecoaman.2012.04.009

Damronkijakarn, N. (2020). การท่องเที่ยวของไทยคงต้องอาศัยการสนับสนุนจากภาครัฐฯ อย่างต่อเนื่อง [Thailand Tourism is always needed subsidy from Government], BusinessToday. (in Thailand).https://www.businesstoday.co/opinions/08/10/2020/51760/

Dimitrovski, D., Lemmetyinen, A., Nieminen, L., \& Pohjola, T. (2021). Understanding coastal and marine tourism sustainability - A multi-stakeholder analysis. Journal of Destination Marketing \& Management, 19(2021). https://doi.org/10.1016/j.jdmm.2021.100554

Fowler, P. (2012). Critical issues affecting the service quality in water-based tour operator: a case study of marine leisure tourist guide in Andaman Cluster, Thailand. Master Dissertation, Prince of Songkla University, Phuket, Thailand.

Knudson, D.M., Cable, T.T., \& Beck, L. (1999). Interpretation of Cultural and Natural Resources, Venture Publishing, Inc., Pennsylvania, USA.

Maakjaeng, S. (1991). Tour Guide Principles, Odean Store, Bangkok, Thailand, (in Thailand).

Mackenzie, S.H., \& Raymond, E. (2020). A conceptual model of adventure tour guide well-being. Annals of Tourism Research, 84(2020). https://doi.org/10.1016/j.annals.2020.102977

Moschino, V., Schintu, M., Marrucci, A., Marras, B., Nesto, N., \& Ros, L.D. (2017). An ecotoxicological approach to evaluate the effects of tourism impacts in the Marine Protected Area of La Maddalena (Sardinia, Italy). Marine Pollution Bulletin, 122(1-2), 306315. https://doi.org/10.1016/j.marpolbul.2017.06.062

Muneenam, U., Suwannattachote, P., \& Mutikasari, R.S. (2017). Interpretation of shared culture of Baba and Nyonya for tourism linkage of four countries in the ASEAN community. Kasetsart Journal of Social Sciences, 38(3), 251-258. https://doi.org/10.1016/j.kjss.2016.08.015

Prakash, M., \& Chowdhary, N. (2010). What are we training tour guides for? (India). Turizam, 14(2), 53-65. https://doi.org/10.5937/ Turizam1002053P

Ratchakitchanubeksa. (2016). พระราชบัญญัติธุรกิจนำเที่ยวและมัคคุเทศก์ (ฉบับที่ ๒) พ.ศ. ๒๕๕ศ [Tourism Business and Guide Act (No.2) B.E. 2016]. (in Thailand). http://www.ratchakitcha.soc.go.th/DATA/PDF/2559/A/076/1.PDF

Sa-nguansil, S. (2015). The effects of recreational feeding on diet, growth, and reproduction of a coral-reef fish, Abudefduf bengalensis (Bloch, 1787), in the Gulf of Thailand, Doctoral Dissertation, Walailak University, Nakhon Si Thammarat, Thailand.

Skibins, J.C. (2016). Tour guiding research: Insights, issues, and implications. Annals of Tourism Research, 60 (2016), 173-175. https://doi.org/10.1016/j.annals.2016.05.001

Thaweerat, P. (1993). Behavioural and social research design, Fingerprint and Media, Bangkok, Thailand.

Thongtham, N., Panchaiphume, P., \& Phoungprasarn, S. (2003). การฟื้นฟูแนวปะการังในทะเลอันดามันของประเทศไทย [Coral reef restoration at Andaman Ocean in Thailand], Distributed Document No.1, Marine and Coastal Resources Research and Development Institute, Department of Marine and Coastal Resources, Bangkok, Thailand, (in Thailand).

Tilden, F. (1977). Interpreting our heritage (3 ed.), The University of North Carlina Press, Chapel Hill, USA.

Wanthanom, C. (2014). Tourist guide. Suan Sunandha Rajabhat University Press, Bangkok, Thailand. (in Thailand)

Weng, L., Laing, Z., \& Bao, J. (2020). The effect of tour interpretation on perceived heritage values: A comparison of tourists with and without tour guiding interpretation at a heritage destination. Journal of Destination Marketing and Management, 16 (June), 1-12. https://doi.org/10.1016/j.jdmm.2020.100431

Weaver, D. (2001). Ecotourism. John Wiley \& Sons Australia, Ltd., Queensland, Australia.

*** Department of Tourism. (2015). Tour Guides Statistics. (in Thailand). https://www.dot.go.th/chart-stat/detail/2

***Jiayun Travel Group Company Limited. (2018). Itinerary of marine and coastal tourism from four to six days to Phuket, Krabi, and Phangnga Destinations [Brochure]. Jiayun Travel Group Company Limited, Phuket, Thailand.

*** Matichononline. (2016). ผู้ประกอบการทัวร์สะท้อน ม.17 กฎเหล็กเที่ยวทะเล [Tour operator reflected to Article 17: Harsh rule of marine tourism]. (in Thailand). https://www.matichon.co.th/local/news_152221

*** Matichononline. (2019). กรมการท่องเที่ยวขยายขอบเขตการทำงานไกด์นำเที่ยวทั่วประเทศ ดีเดย์ 18 เมษายน นี้ [Department of Tourism extends tour guide permission since this coming 18 April]. (in Thailand). https://www.matichon.co.th/publicize/news_1423160

***Ministry of Tourism and Sports. (2017). แผนพัฒนาการท่องเที่ยวแห่งชาติ ฉบับที่ 2 (2560-2564) [National Plan of Tourism, Volume 2 (2017-2021)]. (in Thailand). https://www.mots.go.th/download/article/article_20170320150102.pdf

*** Organization for Economic Co-operation and Development. (1999). Environmental communication: applying communication tools toward sustainable development, OECD Publications, Paris, France.

*** Office of the Council of State. (2008). พระราชบัญญัติธุรกิจนำเที่ยวและมัคคุเทศก์ พ.ศ. ๒๕๕ด [Tourism Business and Guide Act B.E. 2008]. (in Thailand). http//:www.oic.go.th/FILEWEB/CABINFOCENTER3/DRAWER065/GENERAL/DATA0000/00000132.PDF

*** Office of Phuket Statistics Organization. (2019). จำนวนเที่ยวบินขึ้นจง 5 อันดับนักท่องเที่ยวต่างชาติปี 2559 [Top 5 of international airlines arrival in Phuket in 2016]. (in Thailand). http://phuket.nso.go.th/index.php?option=com_content\&view=article\&id=373\&Itemid=646

*** World Tourism Organization (UNWTO). (2021). International Tourism Highlights, 2020 Edition, UNWTO, Madrid, Spain. 